\title{
SISTEM PENDUKUNG KEPUTUSAN PEMILIHAN GUDANG MENGGUNAKAN METODE SINGLE PAGE APPLICATION DAN SIMPLE ADDITIVE WEIGHTING
}

\author{
Erick Sorongan $^{* 1}$, Danar Retno Sari², Putri Apriliza ${ }^{3}$ \\ 1,2,3 Politeknik Negeri Balikpapan \\ Email: 1'erick.sorongan@poltekba.ac.id, ${ }^{2}$ danar.retno@poltekba.ac.id, ${ }^{3}$ putriapriliza98@gmail.com \\ *Penulis Korespondensi
}

(Naskah masuk: 11 Februari 2020, diterima untuk diterbitkan: 08 Juni 2021)

\begin{abstract}
Abstrak
Permasalahan umum pada suatu organisasi berkembang adalah bagaimana mengelola aliran data yang masuk dengan cepat tetapi tetap memperhatikan keakuratan hasil informasinya. Masalah ini sering terjadi terutama pada perusahaan dibidang logistik yang memiliki resiko cukup besar ketika suplai barang dikelola masih menggunakan cara konvensional dengan tingkat kompleksitas tinggi. Tujuan penelitian ini adalah untuk menghasilkan sebuah sistem informasi pendukung keputusan pemilihan gudang sehingga bisa mempersingkat waktu dalam proses pengelolaan barang. Penelitian dilakukan dengan merancang dan mengimplementasikan sebuah sistem informasi pendukung keputusan berdasarkan metode Simple Additive Weighting dalam penentuan gudang tempat penyimpanan barang. Dalam penelitian ini SAW berfungsi untuk melakukan pembobotan berdasarkan kriteria barang sehingga sistem dapat merekomendasikan gudang penyimpanan yang sesuai. Pengkodean sistem menggunakan Single Page Application dengan konsep Model, View dan Controller. Metode seperti ini mampu menghemat bandwith dan sangat cepat ketika diakses karena terdiri atas komponen individual yang dapat diganti atau diperbaharui secara independen, sehingga seluruh halaman tidak perlu dimuat ulang. Penelitian ini mengembangkan metode penjumlahan terbobot yang dikodekan ke dalam bahasa pemrograman dengan menyesuaikan kondisi aliran logistik dan kriteria barang. Kriteria yang digunakan dalam menentukan lokasi penyimpanan barang sesuai dengan jenisnya antara lain, masa penggunaan $(\mathrm{C} 1)$, daya $(\mathrm{C} 2)$, jumlah (C3) dan harga (C4) dengan bobot masing-masing sebesar $25 \%$. Hasil penelitian menunjukkan bahwa sistem ini berhasil memberikan rekomendasi gudang tempat penyimpanan barang sesuai dengan jenisnya. Hal ini dibuktikan dengan cara membandingkan hasil antara perhitungan manual dengan proses inputan sistem menggunakan sample yang sama yakni barang elektronik komputer. Perbandingan menunjukkan hasil yang sama yaitu merekomendasikan barang disimpan ke dalam gudang elektronik.
\end{abstract}

Kata kunci: single page application, $M V C$, sistem pendukung keputusan, $S A W$, pengelolaan barang

\section{DECISION SUPPORT SYSTEM FOR SELECTION OF WAREHOUSE USING SINGLE PAGE APPLICATION AND SIMPLE ADDITIVE WEIGHTING METHODS}

\begin{abstract}
A common problem in a developing organization is how to manage the incoming data flow quickly but still pay attention to the accuracy of the results of the information. This problem often occurs especially in organizations or companies in the field of logistics that have a significant risk when the supply of goods is managed using conventional methods with a high level of complexity. The purpose of this study is to produce an information system supporting warehouse selection decisions so as to shorten the time in the process of managing goods. The study was conducted by designing and implementing a decision support information system based on the Simple Additive Weighting method in determining the warehouse where the goods are stored. In this study SAW functions to do weighting based on the criteria of goods so that the system can recommend an appropriate warehouse. The coding system uses Single Page Application with the concept of Model, View and Controller. This method saves bandwidth and is very fast when accessed because it consists of individual components that can be replaced or updated independently, so that the whole page does not need to be reloaded. This research develops a weighted sum method coded into a programming language by adjusting logistical flow conditions and item criteria. The criteria used in determining the location of storage of goods according to their types include, period of use (C1), power (C2), amount (C3) and price (C4) with a weight of $25 \%$ each. The results showed that this system succeeded in providing recommendations for warehouse storage of goods according to its type. This is evidenced by comparing the results between manual calculations with the input system using the same sample of computer
\end{abstract}


electronic goods. The comparison shows the same results, namely recommending the goods to be stored in an electronic warehouse.

Keywords: single page application, $M V C$, decision support system, SAW, good management

\section{PENDAHULUAN}

Teknologi informasi memberikan keunggulan manajemen kolaboratif pasokan barang (Kembro and Norrman, 2019). Kebutuhan sarana peralatan penunjang produktivitas karyawan di suatu organisasi tentunya akan terus bertambah sesuai dengan kapasitas pelayanan yang diberikannya. Masalah yang sering muncul akibat pengelolaan barang yang bersifat manual adalah sulitnya menentukan alokasi penyimpanan barang jika penginputan dilakukan secara massal dan bervariatif. Untuk menjadikan pengelolaan dan penyimpanan barang menjadi mudah, akurat dan tepat waktu maka dibutuhkan sebuah sistem informasi pendukung keputusan pemilihan gudang barang. Butuh pemahaman yang baik tentang bagaimana mengatur warehouse atau manajemen gudang karena hal tersebut sangat berpengaruh dengan penyaluran logistik dan juga perubahan dalam permintaan konsumen sehingga aliran material atau barang, informasi dan inventory tetap terjaga (Kembro, Norrman and Eriksson, 2018).

Penelitian ini bertujuan untuk merancang dan mengembangkan sistem pendukung keputusan menggunakan model Simple Additive Weighting untuk memberikan rekomendasi tempat penyimpanan barang disuatu gudang penyimpanan yang telah disediakan secara khusus. Alasan peneliti melakukan penelitian ini antara lain : (i) ingin memberikan sebuah solusi dalam mengelola pasokan atau manajemen logistik dengan memanfaatkan sebuah sistem informasi, dan (ii) mengembangkan sebuah sistem informasi yang mampu meningkatkan produktivitas, keakuratan dan efisiensi kerja karyawan karena sistem informasi yang akan dikembangkan nantinya mampu mendukung pengambilan keputusan secara otomatis sesuai dengan kriteria-kriteria yang bisa diadaptasikan dengan kondisi kebutuhan tertentu.

Terdapat beberapa metodologi yang bisa digunakan untuk mengembangkan sistem informasi antara lain, Structured Systems Analysis and Design Method, Join Application Design dan Waterfall. Waterfall dipilih karena memiliki pendekatan pengembangan sistem informasi yang sistematik, mulai dari beberapa tahapan antara lain : system engineering (mempersiapkan segala kebutuhan awal), analysis (memahami sistem yang ada sekaligus mencari solusi permasalahan), design, coding (data yang ada diterjemahkan ke dalam bahasa pemograman), testing (melakukan uji coba sistem) dan maintenance (menerapkan sistem secara keseluruhan sekaligus melakukan pemeliharaan jika terjadi perubahan struktur).
Metodologi waterfall ini pernah digunakan sebelumnya dalam merancang sistem informasi tanaman obat tradisional (Pote, 2018). Metode pendekatan SAW pada penelitian terdahulu digunakan untuk memilih dosen terbaik disalah satu perguruan tinggi dengan menggunakan beberapa kriteria, dan menambahkan metode analytical hierarcy process dalam mengambil keputusan (Laurentinus and Rinaldi, 2019). Sedangkan penelitian berikutnya menggunakan metode SAW dan weighted product untuk memberikan saran masyarakat yang layak menerima bantuan beras bersubsidi dari pemerintah (Berlilana, Prayoga and Utomo, 2018). Hal yang membedakan dari kedua penelitian ini adalah penggunaan metode pengembangan perangkat lunak yang dipakai peneliti saat ini.

Penelitian mengenai sistem informasi menggunakan single page application sudah pernah dilakukan sebelumnya untuk membangun sebuah web application pengisian kartu rencana studi mahasiswa (Ristyabudi and Thamrin, 2016). Perbedaan penelitian ini dengan penelitian sebelumnya menggunakan arsitektur aplikasi basic web architecture HTML 5 dan Angular JS, sedangkan pada penelitian ini menggunakan arsitektur aplikasi web model, view, controller (MVC). Serta pada penelitian ini menggunakan framework laravel karena lebih praktis dan mudah dikonfigurasi, sedangkan pada penelitian sebelumnya menggunakan web framework native. Latar belakang dipilihnya single page application (SPA) adalah SPA memiliki respon yang lebih baik dan enak digunakan, sehingga lebih cepat dalam memproses data yang jumlahnya banyak dalam sekali reload halaman serta informasi yang dihasilkan akurat jika dibandingkan dengan metode lainnya.

Alasan peneliti memilih metode SAW karena model ini terbukti akurat dalam menghasilkan perhitungan alternatif keputusan dengan cara pembobotan kriteria-kriteria yang bisa disesuaikan dengan kebutuhan. Hal ini juga diperkuat dari hasil penelitian (Berlilana, Prayoga and Utomo, 2018) dan (Hardita, Utami and Luthfi, 2019) yang menunjukkan bahwa model ini berhasil digunakan untuk mengambil sebuah keputusan dari berbagai alternatif. Selain itu disebutkan juga bahwa model SAW memiliki keunggulan dibanding model lainnya seperti Weighted Product. Oleh karena itu penelitian ini akan menggunakan model SAW untuk mendukung pengambilan keputusan dalam pemilihan gudang tempat penyimpanan barang. Meskipun model SAW cukup banyak digunakan oleh beberapa peneliti terdahulu, namun yang membedakan kali ini 
adalah peneliti menggunakan model SAW dalam kasus pengembangan sistem informasi untuk logistik yang masih jarang dilakukan. Hal lain yang membedakan adalah kombinasi pengembangan sistem ini menggunakan MVC yang mampu meningkatkan performa dan keamanan sistem. Dalam penelitian ini SAW digunakan untuk menentukan kriteria barang dan mengambil keputusan suatu barang akan disimpan disalah satu dari beberapa pilihan gudang yang tersedia. Diharapkan hasil penelitian ini bisa memberikan rekomendasi atau solusi kepada seluruh organisasi atau perusahaan di bidang logistik dalam mengelola pasokan barangnya dengan memanfaatkan sebuah sistem informasi pendukung keputusan.

\section{METODE PENELITIAN}

\subsection{Tahapan Penelitian}

Secara keseluruhan penelitian ini dilakukan dengan beberapa tahapan, antara lain :

(a) Studi literatur, dimana peneliti melakukan studi berupa materi-materi yang berasal dari penelitian terdahulu, baik tentang pengembangan sistem maupun referensi penggunaan model sistem pendukung keputusan.

(b) Perencanaan sistem, diawali dengan mengumpulkan kebutuhan spesifikasi teknis. Dilanjutkan dengan tahap analisis dan desain sistem.

(c) Implementasi dan uji sistem, tahap ini sangat penting karena masuk kedalam pengembangan sistem melalui pengkodean menggunakan bahasa pemrograman.

Berdasarkan Gambar 1 terdapat alur sistem yang akan dibuat, dimulai dari pengguna masuk ke dalam sistem untuk selanjutnya memilih menu yang ada pada halaman utama. Ketika berada di dalam menu input data, pengguna memasukkan nilai kriteria, selanjutnya sistem akan secara otomatis menghitung bobot kriteria dan hasil perangkingan tiap kriteria. Hasil akhir sistem ini akan memunculkan rekomendasi tempat penyimpanan barang yang dimasukkan ke salah satu gudang yang ada melalui layar pengguna. Seluruh barang yang telah terkategorisasi sesuai dengan hasil rekomendasi penyimpanan gudang akan disimpan ke dalam data base sehingga memudahkan untuk memonitoring stok barang yang tersimpan di gudang penyimpanan.

\subsection{Single Page Application}

SPA terdiri dari komponen individual yang dapat diganti atau diperbaharui secara independen tanpa memperbaharui atau memuat (reload) kembali seluruh halaman, sehingga seluruh halaman tidak perlu dimuat ulang setiap ada aksi dari pengguna (Jadhav, Sawant and Deshmukh, 2015). Tujuan utama SPA memungkinkan cara yang lebih baik dan fleksibel dalam menangani data.

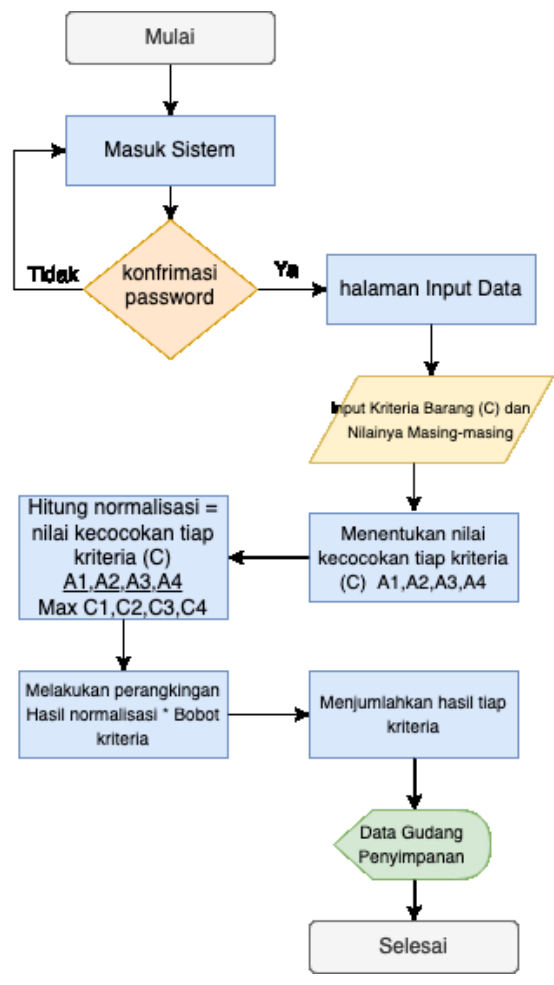

Gambar 1. Proses Pengambilan Keputusan Pemilihan Gudang Menggunakan SAW

Melakukan refreshing bagian tertentu atau keseluruhan suatu halaman, akan tetapi semua fleksibilitas dari SPA membutuhkan antarmuka yang lebih interaktif. Berikut ini adalah perbedaan antara model traditional-client dan SPA-client, seperti tampak pada Gambar 2 proses permintaan layanan dari user membutuhkan pembaharuan halaman sistem secara keseluruhan. Hal tersebut berbeda ketika sistem menggunakan konsep SPA yang menggunakan Javascript untuk pertukaran data antar aplikasi sehingga tidak memerlukan reload page karena menyisipkan halaman lain ke dalam halaman utama. Penggunaan SPA pernah diimplementasikan pada sebuah sistem informasi akademik online (Lokapitasari Belluano, 2018). Hasilnya menunjukkan bahwa SPA mampu mengurangi kinerja beban server saat terjadi permintaan data dari client dan meminimalisir penggunaan sumberdaya oleh server. Penelitian berikutnya juga menunjukkan penggunaan SPA pada proses pengisian data rencana studi mahasiswa (Ristyabudi and Thamrin, 2016), alasan utama penggunaan metode ini adalah jumlah data yang ditransfer dan waktu yang dibutuhkan untuk melakukan pengisian data rencana studi oleh para mahasiswa. Beban kerja sistem dan server akan sangat berpengaruh ketika pengisian harus dilakukan secara bersamaan. Hasil pengujian menunjukkan bahwa pengisian data rencana studi menggunakan aplikasi dengan SPA membutuhkan transfer data kurang dari sepersepuluh detik dari proses pengisian menggunakan aplikasi tanpa SPA. Dari hasil yang 
ditunjukkan oleh kedua peneliti tersebut, peneliti kali ini akan menerapkan SPA dalam pengembangan sistem pendukung keputusan pemilihan gudang untuk menjaga keakuratan data dan kehandalan sistem apabila suatu saat nanti data yang diinputkan jumlahnya melebihi dari yang diperkirakan saat ini.

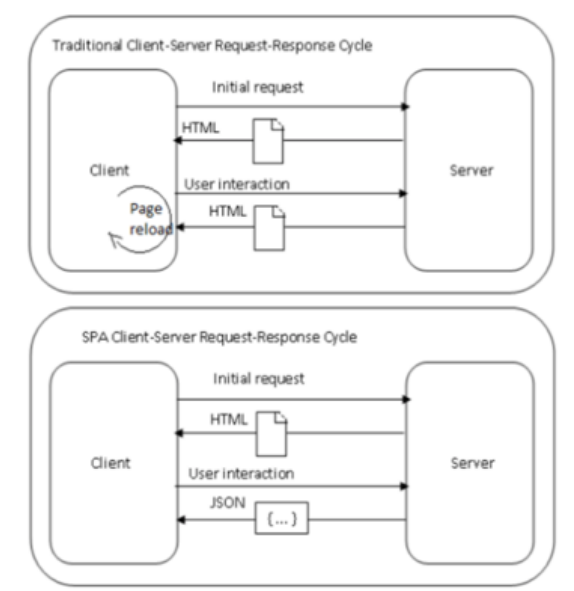

Gambar 2. Perbedaan Respon Permintaan antara Model Tradisional dan SPA (Jadhav, Sawant and Deshmukh, 2015)

\subsection{Vue JS}

Vue JS adalah framework JavaScript yang mendukung SPA untuk membangun aplikasi web, Vue JS juga merupakan library untuk membuat interface web. Sehingga Vue Js merupakan alat yang memanfaatkan arsitektur Model view ViewModel MVVM (Filipova, 2016). Dimana pola arsitektur yang titik utamanya adalah ViewModel yang bertindak sebagai jembatan antara tampilan dan model data sehingga memungkinkan data dialirkan antara view dan model. Penelitian ini memanfaatkan vue JS karena memiliki vue router yang merupakan pembentuk dari metode SPA. Pada Gambar 3 dapat dijelaskan secara singkat bahwa interaksi yang dilakukan oleh user cukup melalui view dimana cara seperti ini lebih meringankan beban sistem ketika diakses dan aman karena operasi data hanya dilakukan pada bagian model. Selain itu ketika ada perubahan komponen view bisa dilakukan secara mandiri tanpa harus memerhatikan bagian lain secara eksesif.

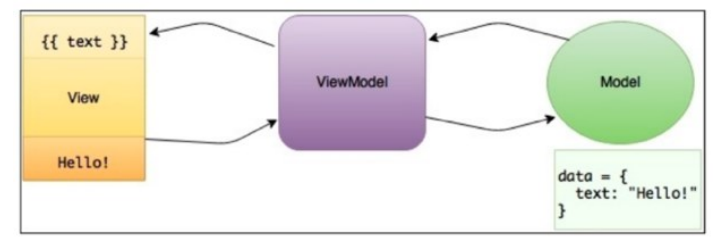

Gambar 3. Diagram Pola Model-View-ViewModel

\subsection{Simple Additive Weighting}

Simple Additive Weighting atau yang dikenal dengan kombinasi linier pembobotan atau metode penilaian adalah teknik multi atribut pengambilan keputusan yang sederhana dan paling sering digunakan (Wang, 2015). Metode ini berdasarkan pada rata-rata pembobotan. Skor evaluasi dihitung untuk setiap alternatif atribut dengan mengalikan nilai skala yang diberikan ke alternatif atribut tersebut dengan bobot yang memiliki arti tersendiri yang langsung ditetapkan oleh pembuat keputusan, diikuti dengan penjumlahan untuk semua kriteria. Keuntungan dari metode ini adalah merupakan hasil transformasi linear proposional dari data mentah yang berarti bahwa urutan relatif besarnya skor yang terstandarisasi tetap sama. Proses SAW terdiri dari langkah-langkah sebagai berikut (Soni, Gautam and Dwivedi, 2018) :

Persamaan (1), menentukan bobot prefensi $(W)$ setiap kriteria atau tingkat kepentingan

$W=\left[W_{1}, W_{2}, W_{3}, W_{4}, \ldots \ldots W_{j}\right]$

Persamaan (2), membuat matrix keputusan $(X)$ yang dibentuk dari tabel rating kecocokan setiap alternatif pada tiap kriteria.

$X=\left[\begin{array}{ccc}X_{11} & \cdots & X_{1 j} \\ \vdots & & \vdots \\ X_{i 1} & \cdots & X_{i j}\end{array}\right]$

Nilai $X$ setiap alternatif $\left(A_{i}\right)$ pada masing-masing kriteria $\left(C_{j}\right)$ yang telah ditentukan, yakni $i=1,2, \ldots m$ $\operatorname{dan} j=1,2, \ldots n$

Normalisasi matrix keputusan dengan cara menghitung nilai rating kinerja yang ternormalisasi $\left(r_{i j}\right)$ dari alternatif $A_{i}$ pada kriteria $C_{j}$, pada persamaan (3)

$r_{i j}=\left\{\begin{array}{l}\frac{X_{i j}}{\operatorname{Max}_{i} X_{i j}} \\ \frac{\operatorname{Min}_{i} X_{i j}}{X_{i j}}\end{array}\right.$

Dimana $r_{i j}$ adalah rating kinerja ternormalisasi dari alternatif $A_{i}$ pada atribut $C_{j}$. Skor akhir dari setiap alternatif dihitung pada persamaan (4) dan kemudian diberi peringkat.

$V_{i}=\sum_{j=1}^{n} w_{j} r_{i j}$

Disini $r_{i j}$ adalah nilai-nilai yang dinormalisasi dari elemen-elemen matrix keputusan. Nilai $V_{i}$ yang lebih besar mengindikasikan bahwa alternatif $A_{i}$ lebih diprioritaskan terpilih (Kembro, Norrman and Eriksson, 2018).

\section{HASIL DAN PEMBAHASAN}

Perancangan sistem pendukung keputusan pemilihan gudang dimulai dengan membuat use case yaitu sekumpulan deskripsi dari aksi atau perilaku yang ditunjukkan oleh sistem. Gambaran sekuens transaksi yang dilakukan oleh actor dan sistem merupakan hasil analisis kebutuhan yang dilakukan pada tahap pengembangan sistem. Sistem ini 
memiliki fungsi diantaranya : (i) permintaan barang, (ii) pemasukkan barang, (iii) pengeluaran barang, (iv) menampilkan stok persediaan barang di gudang dan (v) mencetak laporan sesuai kebutuhan data dari pengguna. Sebelum pengguna berinteraksi menggunakan sistem ini, diwajibkan untuk memasukkan password, hal ini menunjukkan bahwa sistem memiliki intuisi sehingga pengguna yang tidak berhak tidak dapat mengakses data yang ada di dalamnya (Petter, Delone and McLean, 2013). Ketika aktor dalam hal ini admin memilih menu, maka sistem akan menampilkan pilihan yang dapat dilakukan oleh aktor ketika berinteraksi dengan sistem yaitu tambah data $(a d d)$, memodifikasi data (edit), menghapus data (delete) dan menampilkan data (view).

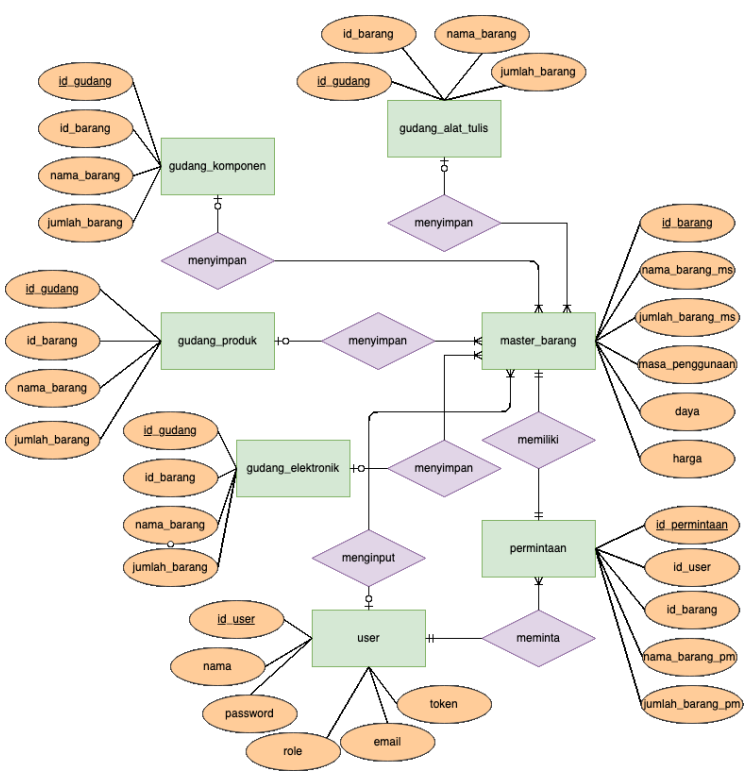

Gambar 4. Entitiy Relationship Diagram Sistem Pengelolaan Barang

Pada Gambar 4 masing-masing entitas menjelaskan hubungannya dengan entitas lain :

1. User memiliki hubungan $1: \mathrm{N}$ pada master_barang. Satu user dapat memasukkan banyak barang pada entitas master barang.

2. User memiliki hubungan $1: \mathrm{N}$ pada entitas permintaan. Setiap user dapat meminta beberapa barang sekaligus.

3. Entitas master barang akan diklasifikasikan berdasarkan kriteria kedalam gudang_prodi dan gudang_sarana yang memiliki hubungan 1:N.

4. Pengeluaran yang dilakukan oleh user akan mengacu kepada entitas gudang yang ada dengan hubungan 1:N.

Setelah perancangan tabel database selesai kemudian diimplementasikan menggunakan DBMS Mysql sehingga setiap tabel yang memiliki relasi sesuai dengan ERD dapat saling terhubung. Tahap berikutnya dalam penelitian ini adalah data yang ada diterjemahkan kedalam bahasa pemograman atau masuk kedalam tahap coding. Penelitian ini menggunakan konsep MVC dan memilih laravel dan Vue Js sebagai framework objek aplikasi backend dan frontend APIs dengan pendekatan SPA, Sehubungan dengan stuktur dasar laravel, backend APIs dianggap terstruktur (Marian and Aurel, 2018) seperti yang disajikan pada Tabel 1 :

\begin{tabular}{|c|c|}
\hline Nama & Deskripsi \\
\hline \multicolumn{2}{|r|}{ Model } \\
\hline User & $\begin{array}{l}\text { Menjelaskan dan berinteraksi dengan } \\
\text { tabel user database }\end{array}$ \\
\hline Content & $\begin{array}{l}\text { Menjelaskan dan berinteraksi dengan } \\
\text { konten tabel database }\end{array}$ \\
\hline Caract_as & $\begin{array}{c}\text { Menjelaskan dan berinteraksi dengan } \\
\text { pemasangan karakteristik tabel } \\
\text { database }\end{array}$ \\
\hline Caract_aux & $\begin{array}{l}\text { Menjelaskan dan berinteraksi dengan } \\
\text { tabel karakteristik bagian controllers }\end{array}$ \\
\hline \multicolumn{2}{|r|}{ Controllers } \\
\hline AuthController & Berisi metode untuk otentikasi \\
\hline ContentController & $\begin{array}{l}\text { Berisi metode untuk create, update, } \\
\text { delete dan lain-lain konten data }\end{array}$ \\
\hline \multicolumn{2}{|r|}{ API routes } \\
\hline api & Berisi REST API routes \\
\hline
\end{tabular}

Alternatif yang digunakan pada sistem ini adalah sebagai berikut :

A1 : Gudang Komponen

A2 : Gudang Elektronik

A3 : Gudang Alat tulis

A4 : Gudang Produk

Selanjutnya, kriteria dan kategori nilai yang ditetapkan untuk mengklasifikasi jenis gudang ke dalam sistem adalah sebagai berikut :

C1 : Masa penggunaan
C1-1 : digunakan $<=5$ kali
C1-2 : digunakan $>=5$ kali
C1-3 : dapat diisi ulang
C1-4 : dapat digunakan berulang

C2 : Daya
C2-1 : $\mathrm{x}>100 \mathrm{v}$
$\mathrm{C} 2-2: 100 \mathrm{v}>\mathrm{x}>=20 \mathrm{v}$
$\mathrm{C} 2-3: 20 \mathrm{v}>\mathrm{x}>=5 \mathrm{v}$
$\mathrm{C} 2-4 \quad: \mathrm{x}<=5 \mathrm{v}$

C3 : Jumlah barang
C3-1 : $\mathrm{x}>=200 \mathrm{pcs}$
C3-2 : 200pcs $>\mathrm{x}>=100 \mathrm{pcs}$
C3-3 : 100pcs $>\mathrm{x}>=50 \mathrm{pcs}$
C3-4 : $\mathrm{x}<50$ pcs

C4 : Harga barang
C4-1 : $\mathrm{x}>=10 \mathrm{jt}$
C4-2 : 500rb $<\mathrm{x}>=10 \mathrm{jt}$
$\mathrm{C} 4-3: 100 \mathrm{rb}<\mathrm{x}>=500 \mathrm{rb}$
C4-4 : $\mathrm{x}<=100 \mathrm{rb}$

Nilai kriteria merupakan bilangan fuzzy yaitu dari $0-1$. Jika nilai 1 artinya kategori tersebut sangat cocok dengan kriteria, sebaliknya jika angka semakin kecil artinya kategori yang dipilih kurang cocok dengan kriteria yang ada. Pada Gambar 5 merupakan halaman kelola kriteria, administrator dapat mengatur ulang nilai bobot setiap kriteria alternatif dengan menekan tombol edit atau tombol hapus. 


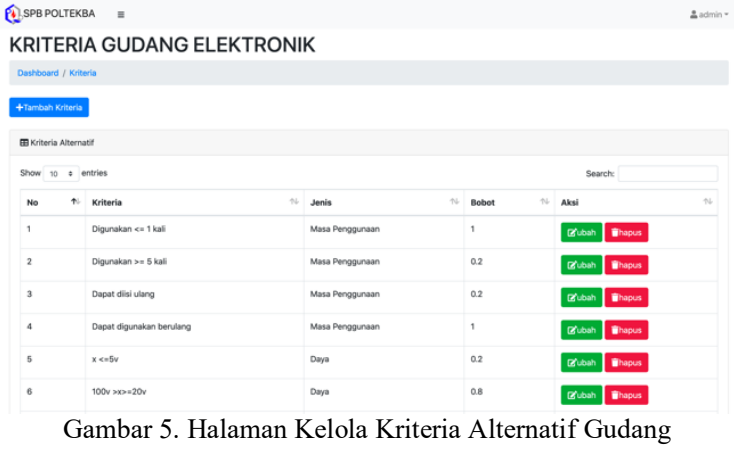

Penentuan kriteria melalui sistem seperti pada Gambar 6 adalah proses pertama yang dilakukan pada saat menghitung menggunakan metode Simple Additive Weighting dengan cara menentukan kriteria (C) dan memberikan value atau nilai pada masingmasing kriteria. Proses ini dapat dilakukan oleh administrator dan operator.

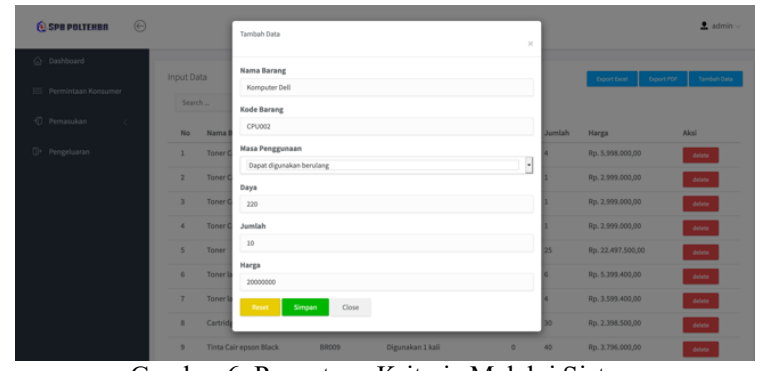

Gambar 6. Penentuan Kriteria Melalui Sistem

Tahap berikutnya setelah ditentukan macam kriteria, sistem melakukan penentuan bobot dan dilakukan normalisasi nilai untuk memperoleh nilai pada skala yang sama. Berikut ini adalah flowchart yang dilakukan untuk menghitung hasil akhir pengambilan keputusan menggunakan metode SAW:

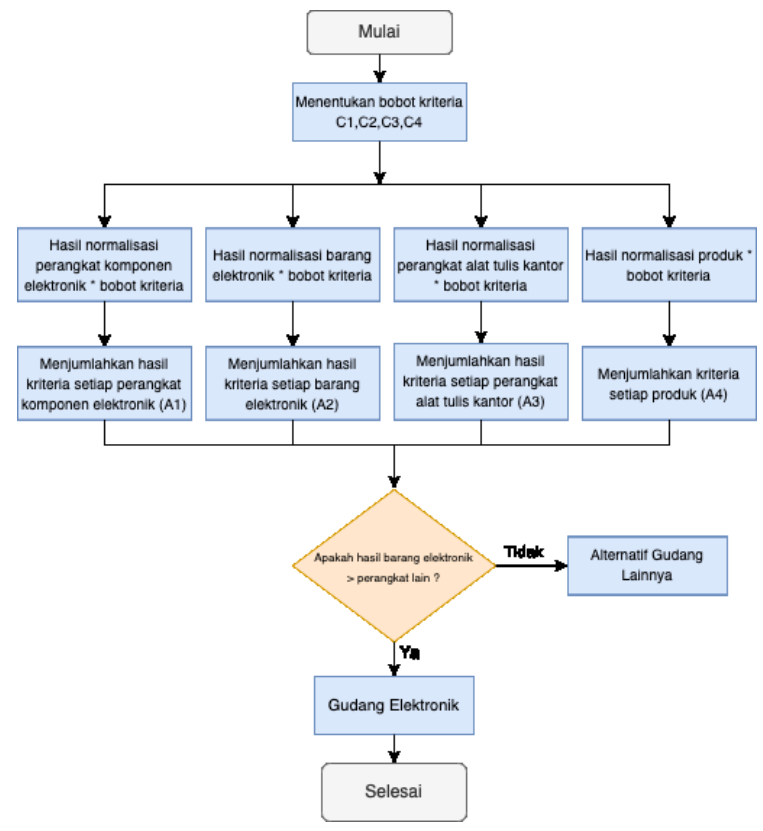

Gambar 7. Cara Perhitungan Akhir Sistem Menentukan Penyimpanan Barang
Pada Gambar 7 menunjukkan flowchart perhitungan hasil akhir didalam sistem ketika barang akan dialokasikan atau disimpan pada gudang yang sesuai dengan jenis barang. Proses diawali dengan normalisasi. Pada contoh kasus kali ini barang yang akan diinputkan untuk ditentukan gudang penyimpanannya adalah barang elektronik. Perhitungan antara hasil normalisasi dikalikan dengan bobot masing- masing kriteria. Hasil dari perkalian tersebut dijumlahkan sesuai alternatifnya. Hasil dari setiap alternatif dibandingkan untuk mendapatkan hasil akhir dari perhitungan, maka nilai yang tertinggi adalah alternatif yang dipilih untuk menentukan letak gudang barangnya. Jika hasil dari Alternatif 2 lebih besar dari pada Alternatif lainnya maka barang tersebut akan masuk ke dalam gudang elektronika, jika tidak maka sistem akan merekomendasikan sesuai peringkat nilai yang terdekat.

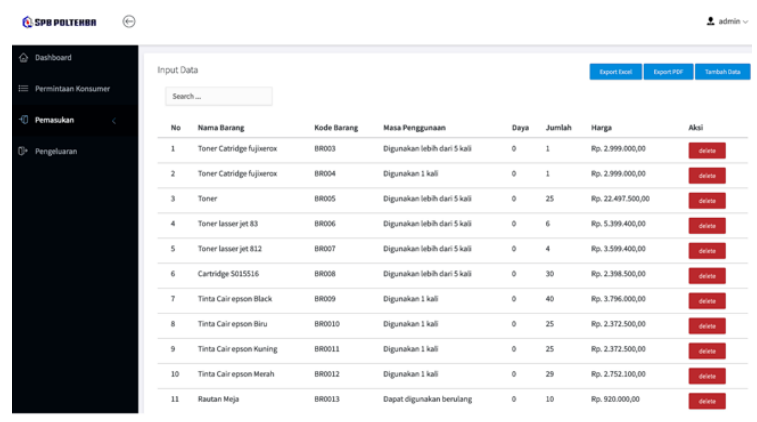

Gambar 8. Halaman Input data Pemasukan Barang

Dalam percobaan awal penelitian ini menggunakan data sebanyak 70 (tujuh puluh) inputan yang disimpan ke dalam tabel master_barang dengan sejumlah atribut seperti yang ditunjukkan pada Gambar 4. Sedangkan aktor yang terlibat dalam sistem ini terdiri atas (a) Operator yang bertugas untuk memasukkan data barang ke dalam sistem sebanyak 5 (lima) orang dan (b) Staff yang melakukan permintaan barang sebanyak 14 (empat belas) orang dimana barang yang diminta akan tercatat sebagai pengeluaran pada sistem. Pada Gambar 8 menunjukkan semua barang yang masuk akan dilakukan pendataan untuk dijadikan sebuah laporan yang bisa dicetak. Barang yang masuk adalah sesuai dengan data permintaan yang sudah dicatat sebelumnya. Pada halaman pemasukan ini akan berjalan sistem pengelolaan barang dengan metode SAW, seperti tampilan Gambar 8. Sistem akan memproses data nama barang, lama penggunaan barang, jumlah, daya dan harga barang sebagai kriteria yang akan diproses dengan metode SAW. Barang yang sudah dimasukkan akan melalui tahap pengambilan keputusan oleh sistem dengan cara memproses data barang dan mengkategorikan barang sesuai jenisnya. 
Berikut ini adalah simulasi perhitungan yang dapat dilihat dengan memasukkan nilai spesifikasi barang sesuai yang ditunjukkan pada Tabel 2 :

1. Terdapat sebuah produk yang akan masuk ke dalam gudang dengan spesifikasi seperti pada Tabel 2 .

Tabel 2. Spesifikasi Barang

\begin{tabular}{lcr}
\hline \multicolumn{3}{c}{ Spesifikasi barang } \\
\hline Nama barang & $:$ & Komputer Dell \\
Masa & $:$ & Dapat digunakan \\
penggunaan & $:$ & berulang \\
Daya & $:$ & $220 \mathrm{~V}$ \\
Jumlah & $:$ & 10 \\
Harga & $:$ & 20 juta \\
\hline
\end{tabular}

2. Menentukan terlebih dahulu bobot kriteria alternatif gudang.

\begin{tabular}{lcc}
\multicolumn{3}{c}{ Tabel 3. Bobot Kriteria Data } \\
\hline Kriteria & Nilai Bobot & Konversi \\
\hline C1 & 25.00 & 0.25 \\
C2 & 25.00 & 0.25 \\
C3 & 25.00 & 0.25 \\
C4 & 25.00 & 0.25 \\
Total & $100 \%$ & 1 \\
\hline
\end{tabular}

Tabel 3 menunjukkan bobot kriteria dan konversi dalam menghitung matriks keputusan, matriks normalisasi, dan skor setiap alternatif.

3. Menentukan nilai alternatif dari setiap kriteria.

Tabel 4. Nilai Alternatif untuk Tiap Kriteria

\begin{tabular}{lcccc}
\hline Alternatif & \multicolumn{4}{c}{ Kriteria } \\
\cline { 2 - 5 } & $\mathrm{C} 1$ & $\mathrm{C} 2$ & $\mathrm{C} 3$ & $\mathrm{C} 4$ \\
\hline $\mathbf{A 1}$ & 0.8 & 0.2 & 0.8 & 0.1 \\
$\mathbf{A 2}$ & 1 & 1 & 1 & 1 \\
$\mathbf{A 3}$ & 1 & 0.1 & 0.6 & 0.2 \\
A4 & 0.5 & 0.6 & 1 & 0.2 \\
\hline
\end{tabular}

Tabel 4 Menunjukkan nilai alternatif setiap kriteria berdasarkan bobot prefensi masingmasing kriteria.

4. Berdasarkan alternatif - alternatif yang ada berupa data gudang menggunakan kriteria dengan beberapa kriteria yang ditentukan, selanjutnya membuat matriks keputusan (X) sesuai dengan Persamaan (2).

$$
X=\left[\begin{array}{cccc}
0.8 & 0.2 & 0.8 & 0.1 \\
1 & 1 & 1 & 1 \\
1 & 0.1 & 0.6 & 0.2 \\
0.5 & 0.6 & 1 & 0.2
\end{array}\right]
$$

5. Langkah berikutnya adalah melakukan normalisasi menggunakan metode simple additive weighting sesuai dengan Persamaan (3).

$$
\begin{aligned}
& r_{11}=\frac{0.8}{\max (0.8,1,1,0.5)}=\frac{0.8}{1}=0.8 \\
& r_{12}=\frac{1}{\max (0.8,1,1,0.5)}=\frac{1}{1}=1 \\
& r_{13}=\frac{1}{\max (0.8,1,1,0.5)}=\frac{1}{1}=1
\end{aligned}
$$

$$
\begin{aligned}
& r_{14}=\frac{0.5}{\max (0.8,1,1,0.5)}=\frac{0.5}{1}=0.5 \\
& r_{21}=\frac{0.2}{\max (0.2,1,0.1,0.6)}=\frac{0.2}{1}=0.2 \\
& r_{22}=\frac{1}{\max (0.2,1,0.1,0.6)}=\frac{1}{1}=1 \\
& r_{23}=\frac{0.1}{\max (0.2,1,0.1,0.6)}=\frac{0.1}{1}=0.1 \\
& r_{24}=\frac{0.6}{\max (0.2,1,0.1,0.6)}=\frac{0.6}{1}=0.6 \\
& r_{31}=\frac{0.8}{\max (0.8,1,0.6,1)}=\frac{1}{1}=0.8 \\
& r_{32}=\frac{1}{\max (0.8,1,0.6,1)}=\frac{1}{1}=1 \\
& r_{33}=\frac{0.6}{\max (0.8,1,0.6,1)}=\frac{1}{1}=0.6 \\
& r_{34}=\frac{1}{\max (0.8,1,0.6,1)}=\frac{1}{1}=1 \\
& r_{41}=\frac{0.1}{\max (0.1,1,0.2,0.2)}=\frac{1}{1}=0.1 \\
& r_{42}=\frac{1}{\max (0.1,1,0.2,0.2)}=\frac{1}{1}=1 \\
& r_{43}=\frac{0.2}{\max (0.1,1,0.2,0.2)}=\frac{0.2}{1}=0.2 \\
& r_{44}=\frac{0.2}{\max (0.1,1,0.2,0.2)}=\frac{0.2}{1}=0.2 \\
& D a r i
\end{aligned}
$$

Dari hasil perhitungan diatas dibuat dalam bentuk matriks normalisasi seperti dibawah ini.

$$
R=\left[\begin{array}{cccc}
0.8 & 0.2 & 0.8 & 0.1 \\
1 & 1 & 1 & 1 \\
1 & 0.1 & 0.6 & 0.2 \\
0.5 & 0.6 & 1 & 0.2
\end{array}\right]
$$

6. Tahap terakhir adalah menentukan prioritas masing - masing alternatif menggunakan rumus Persamaan (4).

$$
\begin{aligned}
V 1= & (0.25 * 0.8)+(0.25 * 0.2)+(0.25 * 0.8) \\
& +(0.25 * 0.1)=0.475 \\
V 2= & (0.25 * 1)+(0.25 * 1)+(0.25 * 1)+ \\
& (0.25 * 1)=1 \\
V 3= & (0.25 * 1)+(0.25 * 0.1)+(0.25 * 0.6) \\
& +(0.25 * 0.2)=0.475 \\
V 4= & (0.25 * 0.5)+(0.25 * 0.6)+(0.25 * 1) \\
& +(0.25 * 0.2)=0.575
\end{aligned}
$$

Tabel 5. Skor Setiap Alternatif pada SAW

\begin{tabular}{llll}
\hline No & $\mathbf{V}_{\mathbf{i j}}$ & Skor & Alternatif Gudang \\
\hline 1 & $\mathrm{~V}_{1}$ & 0.475 & Gudang Komponen \\
2 & $\mathrm{~V}_{2}$ & 1 & Gudang Elektronik \\
3 & $\mathrm{~V}_{3}$ & 0.475 & Gudang Alat Tulis \\
4 & $\mathrm{~V}_{4}$ & 0.575 & Gudang Produk \\
\hline
\end{tabular}

Berdasarkan hasil perhitungan skor setiap alternatif yang ditunjukkan Tabel 5 diatas, berikut ini contoh code penjumlahan bobot pada $\mathrm{A} 2=$ Gudang Elektronik :

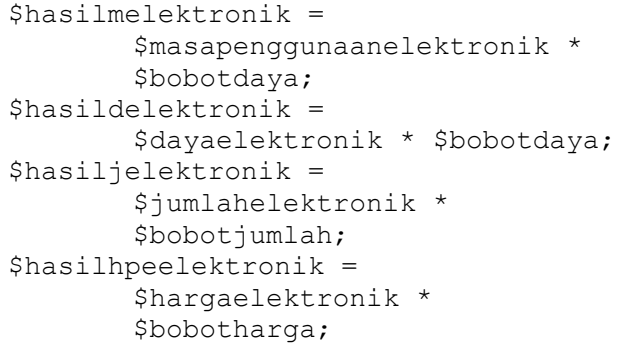




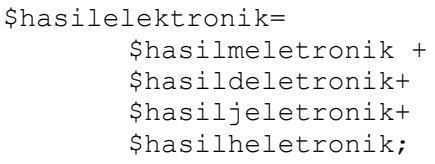

7. Selanjutnya diperoleh bobot kriteria seperti pada Tabel 6 berdasarkan masing-masing alternatif antara lain :

\begin{tabular}{llll}
\multicolumn{4}{c}{ Tabel 6. Penjumlahan Bobot } \\
\hline $\mathbf{A 1}$ & $\mathbf{A 2}$ & $\mathbf{A 3}$ & $\mathbf{A 4}$ \\
\hline 0.475 & $\mathbf{1}$ & 0.475 & 0.575 \\
\hline
\end{tabular}

Sehingga hasil perangkingan setiap alternatif menghasilkan bahwa A2 Gudang Elektronik merupakan tempat yang tepat untuk menyimpan Komputer Dell.

Pada saat proses klasifikasi gudang, data yang sudah dimasukkan pada menu input data pemasukan barang akan diproses dan diolah menggunakan metode SAW di controller. Dalam percobaan ini, kriteria yang diinputkan nilainya sama persis dengan contoh manual Tabel 2. Halaman nilai matriks seperti yang ditunjukkan pada Gambar 9 digunakan untuk melihat nilai masing-masing kriteria yang telah ditentukan oleh administrator. Sedangkan untuk melihat data kriteria tiap alternatif yang telah tersimpan dalam database bisa dilakukan oleh administrator dengan memilih salah satu nilai kriteria gudang pada card berwarna merah, biru, kuning dan hijau. Halaman nilai matriks ini dapat digunakan untuk melihat secara rinci peringkat alternatif gudang yang sesuai dalam bentuk tabel dan disajikan secara eksplisit dengan hasil penilaian tiap kriteria.

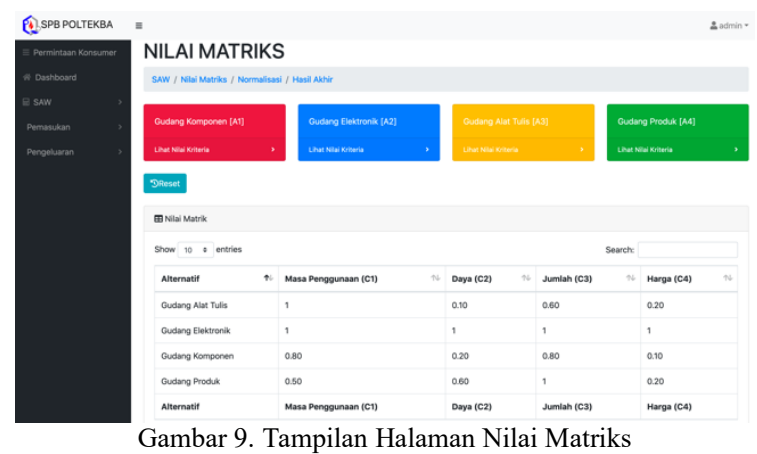

Pada Gambar 10 menunjukkan hasil nilai normalisasi dengan menggunakan rumus Persamaan (3) yang sama dilakukan ketika menghitung secara manual.

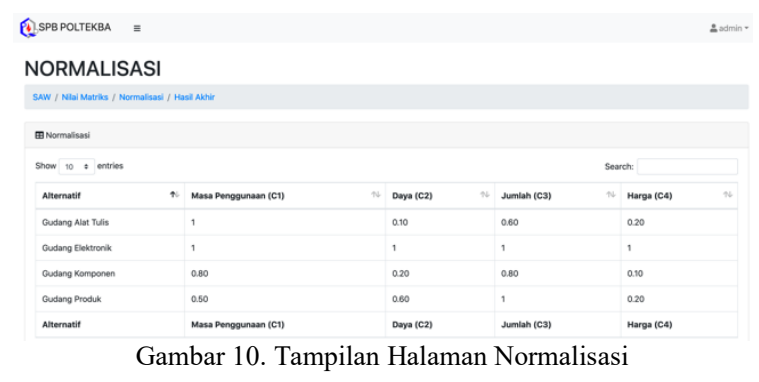

Hasil perhitungan oleh sistem akan dirangking untuk menentukan gudang mana yang cocok dengan nilai barang yang telah dimasukkan sebelumnya. Pada Gambar 11 adalah hasil perangkingan disajikan dalam bentuk diagram batang dan tabel skor akhir. Diagram yang paling tinggi merupakan peringkat teratas dan representasi hasil skor pada tabel. Dalam percobaan kali ini sistem memberi rekomendasi barang disimpan ke Gudang Elektronik.

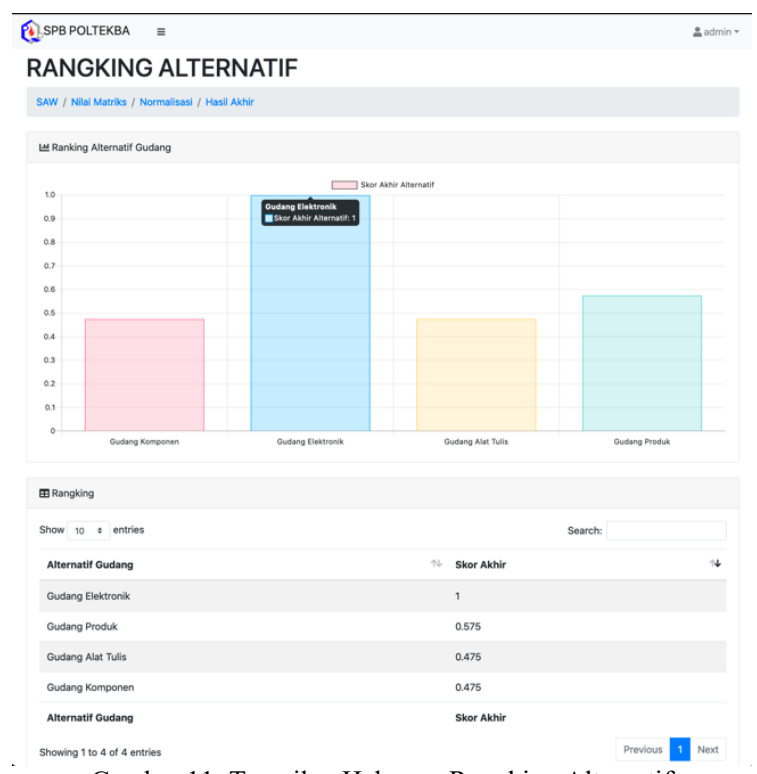

Gambar 11. Tampilan Halaman Rangking Alternatif

Pada Tabel 7 menunjukkan kesesuaian hasil antara simulasi perhitungan manual yang perhitungan yang dilakukan oleh sistem.

Tabel 7. Perbandingan perhitungan manual dan sistem

\begin{tabular}{lcc}
\hline \multicolumn{1}{c}{ Alternatif Gudang } & \multicolumn{2}{c}{ Hasil Perhitungan $\left(\mathbf{V}_{\mathbf{i j}}\right)$} \\
\cline { 2 - 3 } & Manual & Sistem \\
\hline Gudang Elektonik & 1 & 1 \\
Gudang Produk & 0.575 & 0.575 \\
Gudang Alat Tulis & 0.475 & 0.475 \\
Gudang Komponen & 0.475 & 0.475 \\
\hline
\end{tabular}

Pada Gambar 12 merupakan tampilan pada halaman Gudang Elektronik, dimana sistem akan mencatatkan secara otomatis hasil rekomendasi atau perhitungan klasifikasi gudang ke dalam database.

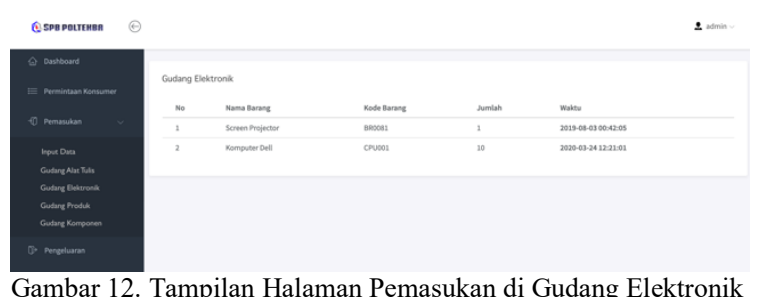

Semua data barang yang masuk ke dalam gudang akan berada pada tabel Gudang Master seperti tampak pada Gambar 13. 


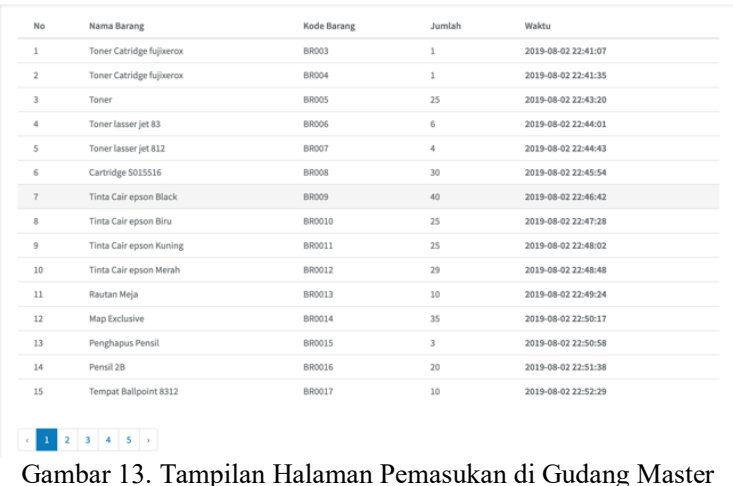

\section{KESIMPULAN}

Sistem pendukung keputusan pemilihan gudang ini telah berhasil dibuat berdasarkan metode simple additive weighting, dengan menggunakan kriteria masa penggunaan, daya, jumlah barang dan harga barang. Dari hasil uji coba yang dilakukan dengan memasukkan data barang dengan spesifikasi antara lain : (i) dapat digunakan berulang kali, (ii) memiliki daya 220 volt, (iii) jumlah 10 buah dan (iv) harga 20 juta sistem secara otomatis merekomendasikan barang tersebut disimpan ke dalam gudang elektronik. Ini juga dibuktikan dengan cara membandingkan hasil perhitungan secara manual dimulai dengan perangkingan kemudian menjumlahkan hasil setiap kriteria maka didapatkan nilai tertinggi 1 untuk kategori gudang elektronika. Sehingga dapat disimpulkan penelitian ini menghasilkan sebuah sistem yang dapat membantu perusahaan untuk mengambil keputusan penentuan gudang penyimpanan barang menggunakan metode SAW secara tepat dan otomatis.

\section{DAFTAR PUSTAKA}

BERLILANA, B., PRAYOGA, F.D. and UTOMO, F.S., 2018. Implementasi Simple Additive Weighting dan Weighted Product pada Sistem Pendukung Keputusan untuk Rekomendasi Penerima Beras Sejahtera. Jurnal Teknologi Informasi dan Ilmu Komputer, 5(4), p.419.

FILIPOVA, O., 2016. Learning Vue.js 2. Birmingham: Packt Publishing Ltd.

HARDITA, V.C., UTAMI, E. and LUTHFI, E.T., 2019. Penerapan Simple Additive Weighting pada Pemilihan Canvasser Terbaik PT.Eratel Prima. Jurnal Teknologi Informasi dan Ilmu Komputer, 6(5), p.567.

JADHAV, M.A., SAWANT, B.R. and DESHMUKH, A., 2015. Single Page Application using AngularJS. (IJCSIT) International Journal of Computer Science and Information Technologies, 6(3), pp.2876-2879.

KEMBRO, J. and NORRMAN, A., 2019. Exploring trends, implications and challenges for logistics information systems in omnichannels: Swedish retailers' perception. International Journal of Retail and Distribution Management, 47(4), pp.384411.

KEMBRO, J.H., NORRMAN, A. and ERIKSSON, E., 2018. Adapting warehouse operations and design to omni-channel logistics: A literature review and research agenda. International Journal of Physical Distribution and Logistics Management, 48(9), pp.890-912.

LAURENTINUS and RINALDI, S., 2019. Implementasi Metode Analytical Hierarchy Process dan Simple Additive Weighting Untuk Pemilihan Dosen Terbaik Studi Kasus STMIK Atma Luhur. Jurnal Teknologi Informasi dan Ilmu Komputer (JTIIK), 6(6), pp.655-664.

LOKAPITASARI BELLUANO, P.L., 2018. Pengembangan Single Page Application Pada Sistem Informasi Akademik. ILKOM Jurnal Ilmiah, 10(1), pp.38-43.

MARIAN, G. and AUREL, A., 2018. A Web Based Appkication Design For Product Data Engineering And Management. U.P.B. Sci. Bull., C.

PETTER, S., DELONE, W. and MCLEAN, E.R., 2013. Information systems success: The quest for the independent variables. Journal of Management Information Systems, 29(4), pp. 7-61.

POTE, J.Y., 2018. Rancang Bangun Sistem Informasi Tanaman Obat Tradisional Menggunakan Framework Code Igniter. Jurnal Teknologi Informasi, XIII, pp.17-28.

RISTYABUDI, A. and THAMRIN, H., $2016 \mathrm{~b}$. Penerapan Single Page Application pada Proses Pengisian Online Data Rencana Studi Mahasiswa. Khazanah Informatika: Jurnal Ilmu Komputer dan Informatika, 2(1), p.1.

SONI, A., GAUTAM, D. and DWIVEDI, A., 2018. Implementation of multi-criteria decisionmaking method for the selection of magnesium alloy to suit the automotive application. 3(6), pp.4-12.

WANG, Y.J., 2015. A fuzzy multi-criteria decisionmaking model based on simple additive weighting method and relative preference relation. Applied Soft Computing Journal, [online] 30, pp.412-420. 
Halaman ini sengaja dikosongkan 